\title{
Danish Literature in Brazil: Notes on Translation and Criticism ${ }^{1}$
}

Vitor Amaral ${ }^{2}$

\section{Introduction}

With a solid however obviously shorter tradition of translation than Europe, Brazil can now be proud of being more central than peripheral in the domain of translation practice and studies. Even if Brazil has a growing editorial industry and a prolific translation market, Brazilian Portuguese $^{3}$ has been the target of few translations from the Danish language. It does not mean that there has not been any literary dialogue between Brazil and Denmark, and this is precisely what this article will approach.

It is the aim of this article ${ }^{4}$ to present some examples of the reception of Danish literature in Brazil through translation and criticism in two sections. The first, 'Translation', will inform the readers of some Danish literary works translated in Brazil. The scope is not to present a comprehensive list of works, but a selection of some representative translations. The second, 'Criticism', will focus on how critics in Brazil received the works of some Danish writers.

\footnotetext{
${ }^{1}$ I wish to thank Karl Erik Schøllhammer, Associate Professor at the Pontifical Catholic University of Rio de Janeiro (PUC-RJ) for thoughtfully receiving me and sending me valuable texts for my research; and Per Johns, essayist, novelist, poet and translator, for the generous exchange of information about Danish literature in Brazil.

${ }^{2}$ From 2005 to 2006, Vitor Alevato do Amaral held a temporary teaching position at the Anglo-Germanic Department in the Faculty of Letters of the Federal University of Rio de Janeiro - UFRJ. He is currently a translator at the UFRJ International Affairs Office and PhD candidate in the Interdisciplinary Programme of Applied Linguistics of the UFRJ Faculty of Letters, developing a project on literary translation and James Joyce's Dubliners.

${ }^{3}$ To avoid ambiguity, henceforth Portuguese means Brazilian Portuguese.

${ }^{4}$ The background to this article is the following: in September 2011, the International Affairs Office of the Federal University of Rio de Janeiro made an official visit to Aarhus University. As part of the delegation, I delivered a lecture in the Center of Brazilian Studies entitled "Translation in Brazil: Facts, Names, and Danish Literature in Brazilian Portuguese". The present is a consequence of that lecture.
} 


\section{Translation}

At least in one aspect Brazilian and Danish literature are in a position very much alike: both depend on translations to be disseminated. That is certainly one of the reasons why the National Library of Rio de Janeiro keeps a program called 'Program for Supporting the Translation and Publishing of Brazilian Authors

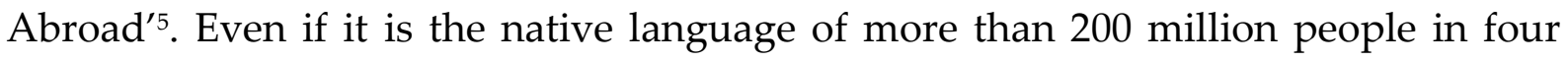
continents, Portuguese is far from having the importance of English in the international scene. The same is true for Danish, only it is spoken by a much smaller number of people. This explains why Ingemai Larsen (2007: 12) refers to the relation between the Danish-speaking and the Portuguese-speaking worlds through translation as a bridge between two peripheries.

However, the strength of a language should not be judged only by the number of people who speak it. The same is true about its literature: 'Danish literature', wrote Per Johns, 'sustained by a language spoken by five million people only, cannot but be considered small, but has its own strength'; for small only means that it is based 'on a language spoken by a few'. Yet, he continues, it 'manifests aspects that one could call strategic, as it superlatively incorporates virtues and flaws of our civilisational progress' (Johns, 2005: 113, 129) ${ }^{6}$.

Preliminarily, I would like to introduce a brief note on Brazilian literature translated in Denmark. According to Ingemai Larsen (2007: 13), two-thirds of the 187 works translated from Portuguese into Danish between 1828 and 2006 were Brazilian works. The first work in Portuguese ever translated into Danish was Os Lusíadas (Die Lusiaden) by Luís de Camões. Only in 1948 a Brazilian work was rendered into Danish: Os Sertões (Oproret paa hojsletten), by Richard Wagner Hansen (Larsen, 2007: 15), followed by Machado de Assis's Memórias Póstumas de Brás Cubas (En vranten

\footnotetext{
${ }^{5}$ For 2012, the budget of the program is US\$ 698,000.00 (www.bn.br).

${ }^{6}$ All the translations into English are my responsibility.
} 
herres betragtninger), by Erick Bach-Pedersen (Brazilian Authors Translated Abroad, 1994: 118$)^{7}$.

It is also worth to note the publication of Opslugt af livet. 21 brasilianske digtere fra det 20 aarhundrede, an anthology of Brazilian poetry organized and translated by Peter Poulsen. As Per Johns (2007: 223) explains, Poulsen's work escapes the 'exotic and socioeconomic common places' that guide other anthologies of Brazilian poetry. Poulsen also translated some poems by Carlos Drummond de Andrade in Verdensfornemmelse og andre digte.

So far, I believe there is not any comprehensive list of Scandinavian or Danish authors translated in Brazil. However, we know that from 1956 to 1980 only 42 works were translated from Scandinavian Languages into Portuguese (Wyler, 2003: 139). Most of those translations were indirect. For instance, the biographical notice present in the 1981 translation of Hans Christian Andersen's Eventyr I Udvalg (Contos de Andersen) affirms that it was the first of Andersen's works to be translated directly from the Danish (Andersen, 1981: 10). The translator was Guttorm Hanssen, and the text was submitted to the stylistic revision of Herberto Sales. It also brings Vilh. Pedersen and Lorenz Frolich's original illustrations.

Other translations of Andersen's works are 'A princesa e o grão de ervilha' ('Prinsessen paa Ærten') and 'Vista de minha janela' ('Udsigt fra Mit Vindue'), found in Jansen and Hansen's Panorama da literatura dinamarquesa. Os pequenos verdes e outras histórias (De smaa Grønne) is a selection of Andersen's tales directly translated by Kristin Lie Garrubo. There is also a direct translation of 'A sombra' ('Skyggen'), first published in 1979, by Aurélio Buarque de Holanda Ferreira e Paulo Rónai. According to Ferreira and Rónai (1999: 261), the source text was Eventur i Udvalg, edited by H.

\footnotetext{
${ }^{7}$ Larsen (2007: 16) affirms that the 1956 translation was of Dom Casmurro. However, the Rio de Janeiro National Library publication Brazilian Authors Translated Abroad refers to Memórias Póstumas de Brás Cubas.
} 
Brix (1918) and, as they stress, 'A sombra' proves that Andersen's stories were not written for children exclusively.

Let us turn our focus to the translations of Jens Peter Jacobsen's works. In a letter of 5 April 1983, addressed to Franz Xaver Kappus - the young poet in Letters to a Young Poet-, Rainer Maria Rilke expresses his opinion about Jacobsen's work:

Of all my books I consider only a few indispensable, and two are always among my possessions wherever I am. Here too they are by my side: the Bible and the books of the great Danish writer Jens Peter Jacobsen. I wonder if you know his works. [...] Acquire the little volume Six Novellas of J. P. Jacobsen and his novel Niels Lyhne, and start [...] with 'Mogens'. A world will open up before you: the happiness, wealth and incomprehensible greatness of a world (Rilke, 2011: 37).

In the following letter, of 23 April 1893, Rilke writes:

Now Niels Lyhne will open up before you, a book of such splendors and depths; the more often one reads it, the more it seems to include everything, from the mildest fragrances of life to the full, rich taste of its heaviest fruits (Rilke, 2011: 38).

The latter excerpt from Letters to a Young Poet was reproduced in Portuguese on the back cover of the Brazilian translation of Niels Lhyne. The reason why? Simple: first published in 1953, Paulo Rónai's translation of Cartas a um jovem poeta (as the title is in Portuguese) has had more than 30 editions, and so popular a book - if I may hazard a guess - must have played a major role in the introduction of Jacobsen to Brazilian readers. 
Per Johns wrote that the Brazilian translation of Niels Lyhne, published in 2002, was made 'con amore, [and is] better than the version published in Portugal (2005: 123). Pedro Octávio Carneiro da Cunha did a relay translation from the German, although the publishing house, Cosac \& Naify, did not make any reference to it ${ }^{8}$. It comes with a prefatory essay by Claudio Magris 'As moedas da vida' - a translation of the Italian 'Le monete della vita'('The Coins of Life') and an annexed translation of 'Arabesk' made by José Paulo Paes. Magris's essay had been originally published in the $80 \mathrm{~s}$ as an introduction to an Italian edition of the novel.

'A peste em Bérgamo' ('Pesten i Bergamo') is part of Jansen and Hansen's Panorama, translated by Per Johns. 'Mogens' appears in Alberto Manguel's anthology Contos de amor do século XIX (Love Stories of the 19th Century) in a direct translation by Kristin Lie Garrubo. It is preceded by a note (by Manguel?), which I reproduce here in translation from the Portuguese:

It is not from today that the Scandinavian literature seems to be more inclined to reflect on reality than to describe it. Perhaps the desolation of the Nordic landscapes contributes to a more meditative mood. It is not that human behaviour is not the theme of that literature; but, once it is approached, the result is less action than reflection. Jens Peter Jacobsen (1847-1885), some of whose texts were set into music by Strindberg, and whose interest in the physical basis of society led him to translate Darwin's The Origin of Species, introduced a sentimental observation of human behaviour in Danish literature. 'Mogens' is his first story, the most naturalist of all, and its

\footnotetext{
${ }^{8}$ Alvaro Luiz Montenegro Valls and Else Hagelund were commissioned by the publishing house to revise the translation, which they did by comparing it with the original in Danish:

(http://www1.capes.gov.br/estudos/dados/2001/42007011/033/2001_033_42007011010P2_Prod_Tec.pdf).
} 
predominant atmosphere is that of loss, sorrow and decay (Jacobsen, 2007: 168).

Ferreira and Rónai also translated 'Um tiro no nevoeiro' ('Et Skud i Taagen') in 1980. The translators clarify in a footnote - with a tremendous sense of respect for the reader, not always shown nowadays - that 'given the impossibility of obtaining the original in Danish, we have translated this short story from two German translations and one Italian one, carefully compared' (Rónai and Ferreira, 1999: 261). The translation is preceded by an introduction - 'Jens Peter Jacobsen' - where Ferreira and Rónai explain that 'Mogens' did not take long to fit the taste of the readers when it was published in 1872 , nor did Jacobsen to be recognized as

the leader of a true artistic revolution [...], one that, unlike all others, was characterized by the combat against noise, glaring colours, resonant words, loud speeches, and came to enthrone a more discreet, veiled, half-toned art, rendering in an apparently simple manner the most complex and pathetic dramas of sensibility, sensuality, instinct and doubt (Ferreira and Rónai, 1999: 259).

They go on in the analysis of the short story and draw our attention to the subtleties in Jacobsen's psychological narrative, urging us to mark the number of words he uses to 'focalise Agatha's personality'. According to the Brazilian translators, Jacobsen 'will make an observation about her hands, seen through the eyes of the person in love with her, and another, very indirect, about her character; during the dialogue, she will hardly say anything; nonetheless, this woman figure is as live as few other literary creations' (Rónai and Ferreira, 1999: 260-261).

In 1993, the Brazilian poet and translator José Paulo Paes (1926- 1998) participated in an international poetry festival in Copenhagen, organized by the poet 
Janus Kodal. Upon his return to Brazil, impressed by the enthusiasm of the audience present at the meeting, he started to study Danish with the purpose of reading poetry. He did so, and more: he translated a selection of fifteen Danish poets out of those anthologized by Jesus Riosalindo in Antologia de la poesia danesa contemporanea (1890-1978), a book introduced to him by Karl Erik Schøllhammer. His other source was Poesi 93, which contains poems by the participants of the 1993 festival. The result was Quinze poetas dinamarqueses (Fifteen Danish Poets), a choice of Danish poets published four years after that festival (Paes, 1997: 9-10).

In a prefatory note to his translations, Paes provides relevant information about his translation process and strategy. He consulted Riosalindo's Spanish version only because it was "faithful to the conceptual meanings of the poems, but not to formal peculiarities such as meter and rhyme. In my versions I tried to make justice to them too". Moreover, he explains that Per Johns revised the translations for him (Paes, 1997: 10-11). His choice consists of the following poets and poems:

1. Jens Peter Jacobsen: 'Arabesk' ('Arabesco')

2. Ludvig Holstein: 'Vil I kende min Veninde?' ('Vocês conhecem a garota?')

3. Sophus Claussen: 'Væk ikke svanerne' ('Não desperteis os cisnes')

4. J. V. Jensen: 'Columbus' ('Colombo')

5. Tom Kristensen: 'Atheisten' ('O ateu')

6. G. M. Petersen: 'Til min forældre' ('Aos meus pais')

7. Tove Ditlevsen: 'Sommernat' ('Noite de verão)' and 'De evig ter' ('O trio eterno')

8. Ole Sarvig: 'Vågen nat' ('Noite de vigília')

9. Erik Knudsen: 'Elegi' ('Elegia')

10. Morten Nielsen: 'Ventetid' ('Tempo de espera')

11. Svend Johansen: 'A rhapsody on melons' ('Uma rapsódia sobre melões’)

12. Inger Christensen: 'Livet, luften vi indånder' ('A vida, o ar que respiramos') 
13. Peter Poulsen: 'Hvis jeg var Hamlet' ('Se eu fosse Hamlet')

14. Pia Juul: 'Roman' ('Romance')

15. Nicolaj Stochholm: 'af Automorfologi' ('de Automorfologia')

It was not the first time 'Arabesk' appeared in Portuguese. Another translation had been published in Panorama da literatura dinamarquesa. This anthology, edited by Billeskov F. B. Jansen and Wagner R. Hansen, and translated into Portuguese by Per Johns, comes to the mind of anyone when the subject is the translation of Danish literature in Brazil. The book is bilingual, apart from the preface and the introduction. The eighth and last section of the book, 'Fire Lyrikere' ('Quatro poetas'), is devoted to poetry. Besides Jacobsen, the other three poets included are Sophus Claussen - 'I en Frugthave' ('Num pomar') and 'Imperia' ('Impéria'); Nis Petersen - 'Forår ved Mariager Fjord' ('Primavera no fiord de Mariager') and 'Elsker du Mennesket?' ('Amas o homem?’); and Thorkild BjØrnvig -'Jalousi’ ('Ciúme’) and 'Ahorntræet' ('O bordo').

'Arabesk' is the poem that seems to have triggered the most interest in Brazil just remember that Paes's translation of that poem would later reproduced in the appendix to the Brazilian translation of Niels Lyhne. For his anthology, Paes wrote the remarkable "Brevíssima notícia da poesia dinamarquesa" ("Very Short Notice of Danish Poetry"). Very concisely, Paes goes through Danish Poetry from the oral ballads of the Medieval Age to the $20^{\text {th }}$ century literary production. Despite its brevity, the text utters some opinions about 'Arabesk':

Jacobsen wrote little poetry. His most famous poem, the 'Arabesque on a Michelangelo's drawing' [...] was written in 1873, when he travelled to Florence. If, to some extent, the landscape evocation to which a good deal of the lines of 'Arabesque' is devoted meets the demands of the nature-oriented lyricism sought by [Georg and 
Edvard] Brandes, the melancholic wondering about the meanings of life and death in the last lines possibly translates existential preoccupations of Jacobsen's, who knew himself tuberculosed by the time he wrote them. However, what is more remarkable in "Arabesque" is that the vehemence of its lyric impetus perfectly matches with the sinuosity of the free verse through which it flows. Such match owes more to the suggestive technique of Symbolism than to the pictorialism of Naturalism and Parnassianism. Most likely, the origin of the name 'Arabesque' [...] is the notion of literary arabesque as developed by Edgar Allan Poe, who entitled one his books Tales of the Grotesque and Arabesque (Paes, 1997: 15-16).

Because Paes declared that the formal aspects of the poem were among his preoccupations, it is relevant to inform the reader that his translation keeps the same number of lines as the original, that is, 98, while Per Johns' translation uses 102. This should by no means be taken as a judgement of the quality of the translations especially because it comes from an author who does not speak Danish -, but as a hint at Paes's concern with form. Below is Paes's translation of 'De evige ter' (Paes, 1997: 62-63). The parenthetical number indicates the quantity of poetic syllables in the line; the letter marks the rhyme scheme.

\section{De evige ter}

Der et to mænd i verden, der bestandig krydser min vej; dene ne er ham jeg elsker, den anden elsker mig.

Den ene er I en natlig drøm, der bor I mit mørke sind,

\section{O trio eterno}

Há dois homens neste mundo (7) que cruzam sempre a minha estrada; $(8$, a) Um é aquele a quem amo, (7) O outro, por quem sou amada. $(7$, a)

Um está nos sonhos que à noite (7 or 8$)$ me enchem de sombras a mente; $(7, \mathrm{~b})$ 
den anden star ved mit hjertes dør, jeg lukker ham aldrig ind.

Den ene gav mig et vårligt pust af lykke, der snart fo' $r$ hen, den anden gav mig sit hele liv og fik aldrig en time igen.

Den ene bruser I blodets sang, hvor elskov er ren of fri, den anden ere eet med den triste dag, drømmente drunker $i$.

Hver kvinde star mellem disse to, forelsket, elsket og ren een gang hvert hundrede år kas det ske, de smelter sammen tile en. à porta do meu coração, (8)

bate o outro inutilmente. $(7, \mathrm{~b})$

Um me deu primaveril (7) ventura logo consumida; $(8, \mathrm{c})$ sem nada ganhar em troca, (7) o outro me deu sua vida. $(7, \mathrm{c})$

Um canta no sangue, onde o amor (8) é puro, livre, risonho; $(7, \mathrm{~d})$ o outro une-se ao dia triste (7) onde se afogam os sonhos. $(7, \mathrm{~d})$

Entre os dois, tão pura e amada (7) é toda mulher que talvez $(8, \mathrm{e})$ ocorra a cada cem anos (7) num só se fundirem os três. $(8, \mathrm{e})$

\section{Criticism}

If translations are a major tool to disseminate a literature in foreign countries, criticism plays as important a role, inasmuch as it haunts our curiosity and deepens our knowledge about foreign works. My goal is to present a review of some texts written in Brazil about Danish authors. Let us begin with José Veríssimo (1857-1916). One of the chapters of Veríssimo's O que é literatura? E outros escritos (What is Literature? And Other Writings), first published in 1907, is 'Um crítico dinamarquês' ('A Danish critic'), devoted to Jorge (sic) Brandes9. Veríssimo regards two of Brandes' books - The Emigrant Literature and L'École romantique en France - as 'monumental', while he portrays Denmark as 'small but very cultured' (Veríssimo, 2001: 173).

Veríssimo emphasises that Brandes was almost unknown in Brazil because he wrote in Danish. The author also mentions that Tobias Barreto (1839-89) had written

\footnotetext{
${ }^{9}$ There is a translation of Brandes' essay " "Det Uendeligt Smaa" og "Det Uendeligt Store" I Poesien' ("O infinitamente pequeno" e "o infinitamente grande" na literatura') in Portuguese (Jansen and Hansen, 1981).
} 
about Brandes, but that Barreto exaggerated the originality of his method, which, in Veríssimos's view, was only 'more universal than [Hippolyte] Taine's' (Veríssimo, 2001: 174). Although Veríssimo does not supply many details about Barreto's discussion, at least he tickles our curiosity about it. To the Brazilian critic, what differentiated between Brandes and other European critics was both his capacity to reach the depths of literatures of various countries without imposing a national point of view and his preoccupation with the spirit of the culture, the unity in the variety of the European civilization' (Veríssimo, 2001: 175).

Otto Maria Carpeaux (1900-1978), an Austrian who chose Brazil as his home, is another important critic and historian of literature. He wrote a beautiful essay called 'As nuanças de Jens Peter Jacobsen' ('The Nuances of Jens Peter Jacobsen'). Originally published in A cinza do purgatório (1942), this article, now collected in Ensaios Reunidos (1999), is considered by Per Johns as the introduction of Jacobsen to Brazilian readers (Johns, 2005: 116). Carpeaux argues that Jacobsen was 'a poet of nuances' and that his

literary influence was immense [for] he remodelled not only the literature but also the language of all Scandinavian nations; penetrated in the feeling and the expression of certain French and German symbolists; rivalled Keat's influence in England; had followers in the Netherlands, in Russia and among the Checks (Carpeaux, 1999: 128).

Carpeaux does not forget to provide the readers with some biographical details. He attempts to wake the readers' attention to an author that he considers 'forgotten', despite all his importance and influence. He also mentions Brandes, but to contradict him: 
The great Danish and European critic Georg Brandes [...] who did a lot for the European glory of Jacobsen, was proud of [the] atheism of his alleged follower. But Jacobsen's agnosticism and realism means another thing: his art, come from deep political agitations, is the transition to a symbolist, symbolic art, transition from the political to the human, of which the Belgian symbolist literature, very Jacobsenian, is another testimony. [...] Brandes did not understand that Jacobsen's atheism was a nuance among a thousand truths of a deep religious anxiety resembling that of his fellow-countryman Kierkegaard (Carpeaux, 1999: 129).

Carpeaux affirms that the style in Maria Grubbe (Marie Grubbe) is a consequence of Jacobsen's beginning, when he wrote the romantic lines of Canções de Gurre (Gurrelieder). 'He intentionally disciplined his language through the archaising artifice of Marie Grubbe and became the greatest artist of prose of the Scandinavian languages' (Carpeaux, 1999: 130). In the critic's description, 'all Niels Lyhne is poetry'. It is a novel where 'outward events are narrated rapidly'. However, since 'the novel is not an art of nuances [...] neither Marie Grubbe nor Niels Lyhne is a novel'. Instead, they are 'episodic works, [for] Jacobsen is, most of all, a short story writer' (Carpeaux, 1999: 131).

Carpeaux emphasises that Jacobsen worked even more slowly on his short stories than on his novels. Summarising Carpeaux's view of them, 'Mogens' is 'romantic'; 'Tiro na névoa' ('Et Skud i Taagen') is 'fantastic'; 'Aqui haveriam de ficar rosas' ('Der burde have været Roser') anticipates neogongorism; 'A peste em Bérgamo' ('Pesten i Bergamo') presents a 'chastely abbreviated style'; and 'Senhora Foenss' ('Fru Fønss') is an example of 'psychological nuance' (Carpeaux, 1999: 132). 
In História da literatura ocidental (History of Western Literature) $)^{10}$, Carpeaux (2008: 1919) writes that Jacobsen 'is an angelic figure, one of the most delicate of the late $19^{\text {th }}$ century, and his presence between Brandes's radical positivists and the naturalists in the style of Zola seems to be a mistake committed by history'. Carpeaux also finds some traces of the Romantic irony in Jacobsen's style:

He was and would always be prevented from professing a more positive faith, even the vague faith of neo-romanticism, for he was an ironic spirit, descended from a rare romanticism, destructive without eloquence, and so much so that he seems to be the most antiromantic of the romantics (Carpeaux, 2008: 1919).

Niels Lyhne is regarded as a 'psychological novel in the most intense lyricism', and, echoing his own thoughts in 'As nuanças de Jens Peter Jacobsen', Carpeaux affirms again that Niels Lyhne 'is more a novella than a novel; a series of impressionistic canvases that remind us of Degas' art' [...]; works in which 'Gongorist virtuosities' are seen. Marie Grubbe is also made of a 'series of impressionistic canvases', a novel where, through 'verbal artifice', Jacobsen realized 'a perfect imitation of the archaic language, an outstanding recreation of the late $17^{\text {th }}$ century Denmark [...]' (Carpeaux, 2008: 1919-1920).

Emphasising the plasticity of Jacobsen's impressionistic writing, Carpeaux concludes that 'he was not a born novelist. He was an artist of the plastic values': just like in the painting of the French impressionists, 'in Jacobsen's descriptions, light performs a major role, and the very soul of the things depends on the modifications of lighting [...]' (Carpeaux, 2008: 1920).

\footnotetext{
${ }^{10}$ First published in 1947, Carpeaux's tour de force is a unique history of Western literature, where Brazilian authors, with whom he was already familiar, share space with the greatest writers of the European and United States literature.
} 
In 2005, Per Johns published a collection of essays named Dioniso Crucificado (Dionysus Crucified). Some of the essays collected are about Denmark and Danish literature. For the sake of coherence, I will concentrate on 'Jacobsen: vidas em surdina' ('Jacobsen: silent lives'). Johns' main idea is that 'Jacobsen's literature runs in the interior of his characters, in silent battles, without screams or ostentation'; his writing was 'intensive' and he tried to look from the inside, when the vogue was an 'extensive' literature that tried to comprehend the world from the outside (Johns, 2005: 116-117). As we can easily notice, Johns' view chimes with Carpeaux's. Johns also stresses the fusion of poetry and prose which gave Jacobsen the title of 'master of the language', even though his writing was so different from the standards of his time that 'the majority preferred the noise of Karl Gjellerup to the strange silence of Jacobsen' (Johns, 2005: 119).

In Johns' reading, while the characters of Marie Grubbe are unfinished, Jacobsen's style is not:

For sure, one of the reasons that explain the contemporaneity of Marie Grubbe is the fact that its characters are unfinished and its themes remain open, in the sense that they do not bring answers but new questions, as life itself $[\ldots]$. The same cannot be said about Jacobsen's style, which is finished, perfect; form and content mingle and make every word essential (Johns, 2005: 120-121).

Carpeaux brought out the impressionistic traces of Jacoben's writing. Johns, instead, reminds us that Jacobsen's style was called cinematographic avant la lettre:

It was said that Jacobsen's style was cinematographic avant la lettre. And some saw in his breath, alternating long sentences - some enormous - with telegraphic ones, the cadence in which nature and 
the facts run differentiated through the characters. Some events are not even articulated but only suggested, and yet they appear as clear as an image (Johns, 2005: 121).

In 2006, three articles about Hans Christian Andersen appeared in an issue of Multitextos: 'Hans Christian Andersen: 200 anos de fantasia e verdade' ('Hans Christian Andersen: 200 Years of Fantasy and Truth'). Given the scope and limited length of the present article, I will not do more than introducing each one of them. Karl Erik Schøllhammer's 'Hans Christian Andersen. Vida e obra' ('Hans Christian Andersen. Life and Work') opens the collection. It is a detailed account - more than the brief ones that I have come across so far- of Andersen's life and work. The text contextualizes Andersen's writing, highlighting the turmoil of the war and the economic crisis of the early 1800s as well as the cultural and artistic ferment of the Golden Age of arts in Denmark during Romanticism.

Eliana Yunes' 'Andersen: duzentos anos de fantasia e verdade' ('Andersen: Two Hundred Years of Fantasy and Truth) examines the endurance of Andersen's work in the light of its relation with society. She resorts to Freud, whose theories changed our perception of fantasy from a sign of craziness to the work of the unconscious. Yunes finishes her article with a very interesting comparative reading of Andersen's 'A pequena vendedora de fósforos' ('Den Lille Pige med Svovlstikkerne') and Dostoyevsky's 'A árvore de natal na casa do Cristo' ('The Heavenly Christmas Tree').

Last, in 'As duas realidades de Hans Christian Andersen' ('The Two Realities of Hans Christian Andersen'), Per Johns is critical about the literary canon, which labels Andersen's tales as children's literature and embraces only half of his production. Also worth to note is the observation he makes on the translation of the word eventyr into English and Portuguese. Neither 'fairy tale' nor 'conto de fadas' covers the scope of the Danish word, which means "more or less the adventure of 
trespassing established boundaries to reach the conflicts of an imagination that does not exclude the real' (Johns, 2006: 37).

\section{Conclusion}

One can of course ask, 'why translate and write about Danish literature in Brazil, when Denmark is so distant on the map, when little is known about this country?' Because the fact that Denmark is not a Brazilian tourists' favourite destination does not diminish our interest in its literature; instead, it triggers translators' and critics' anxiety for discovering its richness and bringing it to light.

José Paulo Paes's Translation, for instance, teaches us never to belittle the importance and the reach of individual initiatives. The translators and critics of Danish literature in Brazil are few, that is right, but their work is a bridge whose arches are the belief in literature as a way to unite people, as a force against intolerance and ignorance.

This paper was written under the timid light that illuminates the researcher's first steps. Thus it is, unashamedly, nothing more than a personal perception about Danish literature translated and criticised in Brazil. My hope lies in that the future researcher, interested in delving into the theme, may find this text as a door left ajar, waiting to be open widely.

\section{Works Cited}

Andersen, Hans Christian. Contos de Andersen. $3^{\text {rd }}$ ed. Trans. Guttorm Hanssen. Paz e Terra: Rio de Janeiro,1981.

- 'Hans Christian Andersen', 'A sombra', in Holanda, Aurélio Buarque de and Rónai, Paulo (eds.) Mar de histórias. Trans. Aurélio Buarque de Holanda and 
Paulo Rónai. Vol 3. $4^{\text {th }}$ edition. Nova Fronteira: Rio de Janeiro, 1999. pp.259-261, 262274.

Os pequenos verdes e outras histórias. Lisbeth Zwerger, ed. Trans. Kristin Lie Garrubo. Berlendis \& Vertecchia Editores: São Paulo, 2011.

Brazilian Authors Translated Abroad. Fundação Biblioteca Nacional: Rio de Janeiro, 1994.

Carpeaux, Otto Maria. 'As nuanças de Jens Peter Jacobsen', in Ensaios Reunidos. 19421978. Vol. 1. Univercidade / Topbooks: Rio de Janeiro, 1999. pp. 127-133.

História da literatura ocidental. Vol. 3. 3². ed. Senado Federal: Brasília, 2008.

Jacobsen, Jens Peter. Niels Lyhne. Trans. Pedro Octávio Carneiro da Cunha. Cosac \& Naify: São Paulo, 2003.

- 'Mogens'. Trans. Kristin Lie Garrubo. Contos de amor do século XIX, in Alberto Manguel (ed.) Companhia das Letras: São Paulo, 2007. pp. 168-201.

- 'Jens Peter Jacobsen' and 'Um tiro no nevoeiro', in Holanda, Aurélio Buarque de e Rónai, Paulo (eds.) Mar de histórias. Trans. Aurélio Buarque de Holanda and Paulo Rónai. Vol. 4, $4^{\text {th }}$ ed. Nova Fronteira: Rio de Janeiro, 1999. Pp. 259-261, 262276.

Jansen, Billeskov F. B. and Hansen, Wagner R. Panorama da literatura dinamarquesa. Trans. Per Johns. Nórdica: Rio de Janeiro, 1981.

Johns, Per. Dioniso Crucificado. Topbooks: Rio de Janeiro, 2005. .'As duas realidades de Hans Christian Andersen'. Multitextos 4, 2006.pp. 3754.

. 'Absortos na vida'. Poesia Sempre, no. 26. 2007. pp. 223-230.

Larsen, Ingemai. 'De uma periferia à outra na tradução português-dinamarquês'. Cadernos de tradução 19:1, 2007. pp. 11-24.

Magris, Claudio. 'As moedas da vida'. Trans. Julia Marchetti Polinesio, in Jacobsen, Jens Peter. Niels Lyhne. Trans. Pedro Octávio Carneiro da Cunha. Cosac \& Naify: São Paulo, 2003, pp. 7-28. 
Paes, José Paulo (ed.) Quinze poetas dinamarqueses. Trans. José Paulo Paes. Letras contemporâneas: Florianópolis, 1997.

Rilke, Rainer Maria. Letters to a Young Poet. Trans. Mark Harman. Harvard University Press: Harvard, 2011.

Schøllhammer, Karl Erik. 'Hans Christian Andersen: vida e obra'. Multitextos 4, 2006. pp. 3-12.

Veríssimo, José. 'Um crítico dinamarquês', in O que é literatura? E outros escritos. Landy: São Paulo, 2001, pp.173-181.

Wyler, Lia. Linguas, poetas e bacharéis. Uma crônica da tradução no Brasil. Rocco: Rio de Janeiro, 2003.

Yunes, Eliana. (2006) 'Andersen: duzentos anos de fantasia e verdade'. Multitextos 4, 2006. pp. 13-35. 